im. Bł. ks. W. Findysza w Jaśle

\title{
Instytucje otoczenia biznesu jako czynnik wspomagający rozwój przedsiębiorczości w woj. podkarpackim
}

Fundamentalne znaczenie instytucji otoczenia biznesu w funkcjonowaniu oraz rozwoju gospodarki społeczeństwa jest już w naukach społecznych powszechnie akceptowane. Nurty instytucjonalne, zwłaszcza tzw. nowa ekonomia instytucjonalna, należą do najszybciej rozwijających się i najpłodniejszych poznawczo nurtów teoretycznych współczesnej ekonomii. Według współczesnych instytucjonalistów ekonomia nie może ograniczać się do badania zjawisk rynkowych; powinna również uwzględniać pozarynkowe ramy, w jakich podejmowane są decyzje gospodarcze. Powinna więc badać instytucje społeczne, które mają istotne znaczenie dla zachowań ekonomicznych: władze państwowe, związki zawodowe, organizacje finansowe, organizacje społeczno-polityczne, a także struktury własnościowe, organizacyjne itd. ${ }^{1}$

Znaczenie pojęcia ,instytucja” jest bardzo szerokie i przez przedstawicieli poszczególnych dyscyplin naukowych różnie interpretowane. Według D.C. Northa, przedstawiciela nowej ekonomii instytucjonalnej, są to trwałe, prawne, organizacyjne i zwyczajowe uwarunkowania powtarzalnych ludzkich zachowań i międzyludzkich interakcji ${ }^{2}$. Z tego wynika, że instytucja to zespół funkcjonalnie powiązanych norm prawnych i zasad, jak również wyodrębniona struktura organizacyjna (organizacje) i mechanizmy jej funkcjonowania.

Sfera instytucjonalna jest najważniejszym czynnikiem różnicującym rozwój gospodarczy regionów, gałęzi i całych gospodarek narodowych. Składa się na nią skomplikowana sieć instytucji formalnych i nieformalnych; niektóre z nich powstają bardzo długo i zmieniają się powoli. Dotyczy to zwłaszcza instytucji społecznych nazywanych instytucjami nieformalnymi, których przykładami są normy moralne, etyka, tradycje, utrwalone sposoby zachowań czy sposoby myślenia ${ }^{3}$. Instytucje formalne to system norm prawnych i organizacji powołanych do ich egzekwowania, a także złożony układ różnego rodzaju organizacji gospodarczych, politycznych, społecznych i kulturalnych, które regulują zachowania ludzi w tych dziedzinach życia oraz determinują efekty tych zachowań, w tym efekty ekonomiczne ${ }^{4}$.

Takie ujęcie jest zbliżone do tradycyjnego (potocznego) i sformalizowanego rozumienia i określania instytucji, głównie przez pryzmat struktur organizacyjnych i realizowanych funkcji 5 .

${ }^{1} \mathrm{~J}$. Wilkin, 2001, Instytucjonalne uwarunkowania modernizacji wsi $w$ Polsce, ZN AR w Krakowie, nr 377, z. 78, t. I, Kraków.

${ }^{2}$ D.C. North, 1990, Institution, Institutional Change and Economic Performance, Cambridge University Press.

${ }^{3}$ J. Wilkin, 1997, Instytucje i instytucjonalizm w ekonomii, WNE, Warszawa.

${ }^{4} \mathrm{~J}$. Wilkin, 2001, Instytucjonalne uwarunkowania modernizacji wsi $w$ Polsce, ZN AR w Krakowie, nr 377, z. 78, t. I, Kraków.

${ }^{5}$ T. Dołęgowski, 2002, Konkurencyjność instytucjonalna i systemowa w warunkach gospodarki globalnej, „Monografie i Opracowania”, 505, Wyd. SGH, Warszawa. 
Pośród instytucji wspierających rozwój regionalny, stosując kryterium formy organizacyjno-prawnej i formy własności tych organizacji, możemy wyróżnić6:

- jednostki administracji publicznej,

- instytucje przedstawicielskie biznesu,

- stowarzyszenia i fundacje pozarządowe,

- spółki publiczno-prywatne,

- jednostki szkół wyższych i instytucji naukowych.

\section{Instytucjonalny aspekt procesów gospodarczych regionu}

Rozwój regionalny, definiowany jako proces zmian w sferze gospodarczej, ekonomicznej i społecznej, nie odbywa się samoistnie. Kreowany i urzeczywistniany jest przez wiele różnego rodzaju czynników, od generalnych do szczegółowych czy nawet detalicznych. Ich walory jakościowe i ilościowe mają duże znaczenie dla polityków, ekonomistów, kadr samorządowych, społeczności regionów, ponieważ to one przesądzają o tempie rozwoju regionu? Istotnym czynnikiem rozwoju regionu jest infrastruktura instytucjonalna określana jako:

- struktura społeczno-ekonomiczna, którą tworzą: agencje rozwoju gospodarczego, izby handlowo-przemysłowe, towarzystwa rozwoju, organizacje systemu kształcenia i doskonalenia;

- struktura finansowa reprezentowana przez banki, kasy oszczędnościowo-pożyczkowe, towarzystwa inwestycyjne, fundacje rozwoju, fundusze wspierania gospodarczego, towarzystwa asekuracyjne itp.;

- struktura polityczna tworzona przez różnego rodzaju ośrodki i instytucje władzy oraz działalności politycznej;

- struktura oświatowa, czyli różnego rodzaju szkoły i instytucje kształcenia i doskonalenia. Niedorozwój infrastruktury instytucjonalnej nie sprzyja rozwojowi społeczno-gospodarczemu. Uważany jest za barierę rozwoju regionu ${ }^{8}$. Głównym zadaniem instytucji wspierających rozwój regionalny jest tworzenie sprzyjających warunków do podnoszenia atrakcyjności inwestycyjnej regionu, a tym samym - podnoszenia jego konkurencyjności. Ze względu na charakter działalności i realizację specyficznych zadań, funkcjonujące na obszarze woj. podkarpackiego instytucje rozwoju regionalnego można podzielić na dziewięć grup. Ich zadaniem jest podejmowanie działań na rzecz rozwoju regionu oraz wyrównywanie nierówności w jego obrębie. Szczególne zadanie przypisano agencjom regionalnym, izbom i stowarzyszeniom gospodarczym oraz ośrodkom wspierania przedsiębiorczości. Układ instytucjonalny kreujący rozwój regionu to:

- agencje rozwoju regionalnego,

- izby i stowarzyszenia gospodarcze,

- ośrodki wspierania przedsiębiorczości,

- specjalne strefy ekonomiczne,

- centra wspierające wdrażanie innowacji i zajmujące się transferem technologii,

- centra targowe, wystawienniczo-promocyjne, giełdy towarowe,

- ośrodki doradztwa i informacji gospodarczej,

${ }^{6}$ E. Zeman-Miszewska, 2006, Instytucjonalne formy wspierania przedsiębiorczości, „Prace Naukowe AE we Wrocławiu", 1116, s. 687-691.

${ }^{7}$ K. Gawlikowska-Hueckel, 2003, Procesy rozwoju regionalnego w Polsce $i$ w Unii Europejskiej, UG, Gdańsk, s. 134.

${ }^{8}$ M. Klamut, 2000, Uwarunkowania podnoszenia konkurencyjności regionów w Polsce [w:] Konkurencyjność gospodarcza regionu $w$ warunkach nowego ustroju terytorialno-administracyjnego, W. Kosiedowski (red.), Wydawnictwo Uniwersytetu Mikołaja Kopernika, Toruń, s. 289 i 290. 
- organizacje zajmujące się pośrednictwem pracy i innymi formami przeciwdziałania bezrobociu,

- instytucje finansowe.

Oto najważniejsze dla regionu Podkarpacia instytucje, które znacząco przyczyniają się do jego rozwoju.

\section{Agencje rozwoju regionalnego}

Tworzenie agencji rozwoju regionalnego w Polsce zainicjowała UE. Jest to efekt szeroko rozumianej demokratyzacji państwa. Większość agencji ma charakter spółek akcyjnych, nieliczne działają $\mathrm{w}$ formie fundacji czy spółek $\mathrm{z}$ ograniczoną odpowiedzialnością. Jednostki te są finansowo wspierane $\mathrm{z}$ budżetu centralnego bądź samorządowego, co jest cechą odróżniającą je od takich instytucji w UE, mimo że ze Wspólnoty czerpano ogólne wzorce organizacji i funkcjonowania agencji w Polsce. Proces tworzenia agencji to inicjatywa władz wojewódzkich i samorządowych. Agencje rozwoju regionalnego działają na rzecz aktywizacji gospodarczej regionu, wypełniają strukturalną lukę pomiędzy administracją rządową, jednostkami samorządu terytorialnego oraz podmiotami gospodarczymi i bankami. Do zadań tych instytucji należą:

- efektywne wykorzystywanie i obsługa środków UE,

- wspieranie rozwoju przedsiębiorczości,

- poszukiwanie i obsługa inwestorów krajowych i zagranicznych,

- współpraca z samorządem terytorialnym,

- prowadzenie doradztwa i szkoleń,

- wspieranie procesów restrukturyzacyjnych i przekształceń własnościowych w przedsiębiorstwach,

- promowanie potencjału regionu,

- tworzenie instytucji otoczenia biznesu w regionie,

- rozwijanie współpracy międzynarodowej w strukturach Unii Europejskiej.

Założycielami-fundatorami instytucji otoczenia biznesu były m.in. lokalne samorządy, Skarb Państwa, przedsiębiorstwa i firmy prywatne, banki, związki zawodowe i inne instytucje. Oprócz wymienionych jednostek, na obszarze województwa działają inne fundacje i fundusze, które poprzez realizację swoich statutowych zadań wspomagają rozwój przedsiębiorczości, agrobiznesu, edukacji, ochrony zdrowia, ochrony środowiska, a także umożliwiają nawiązywanie kontaktów międzynarodowych. Ze względu na zakres działania i skład akcjonariatu (samorząd woj. podkarpackiego - 71\% kapitału zakładowego), największy wpływ na rozwój Podkarpacia wywiera działalność Rzeszowskiej Agencji Rozwoju Regionalnego z siedzibą w Rzeszowie. Instytucja ta współpracuje z PARP we wdrażaniu środków UE z przeznaczeniem na rozwój przedsiębiorczości i innowacyjności.

\section{Specjalne strefy ekonomiczne}

W woj. podkarpackim funkcjonują trzy specjalne strefy ekonomiczne:

- Specjalna Strefa Ekonomiczna EURO-PARK Mielec w Mielcu,

- Specjalna Strefa Ekonomiczna EURO-PARK WISŁOSAN,

- podstrefa krakowskiej specjalnej strefy ekonomicznej, powołana rozporządzeniem Rady Ministrów z 19.06.2006 r., zmieniającym rozporządzenie w sprawie krakowskiej specjalnej strefy ekonomicznej (DzU Nr 118, poz. 803), w Krośnie.

Specjalna Strefa Ekonomiczna w Mielcu ma następujące podstrefy na obszarze woj. podkarpackiego: Dębica, Głogów Małopolski, Jarosław, Laszki, Leżajsk, Lubaczów, Ostrów, Ropczyce, Sanok, Trzebownisko i Zagórz, a poza obszarem Podkarpacia - w Gorlicach 
i Lublinie. Strefa tarnobrzeska działa w Stalowej Woli, Tarnobrzegu i Nowej Dębie. Jej podstrefy znajdują się w Jaśle i Przemyślu, a poza woj. podkarpackim - we Wrocławiu-Kobierzycach, Radomiu, Staszowie, Janowie Lubelskim, Tomaszowie Lubelskim, Siedlcach i Łukowie.

Specjalne strefy ekonomiczne są zarządzane przez oddziały Agencji Rozwoju Przemysłu S.A. Dzięki ustawowym ulgom są obszarami przyciągającymi inwestycje, zarówno krajowe, jak i zagraniczne, w dużym stopniu łagodzącymi skutki transformacji społeczno-gospodarczej na terenach funkcjonowania tradycyjnych, schyłkowych gałęzi przemysłu. SSE przyczyniają się do aktywizacji i rozwoju przedsiębiorczości w regionie. Na przykład, według stanu 31 grudnia 2007 r. w strefie mieleckiej zainwestowano 3,114 mld zł i stworzono 13104 miejsca pracy, a w strefie tarnobrzeskiej zainwestowano 4,129 mld zł i stworzono 18799 miejsc pracy.

\section{Instytucje finansowe}

Instytucje finansowe to głównie banki i towarzystwa ubezpieczeniowe, które świadczą usługi finansowe na rzecz podmiotów w regionie. W większych miastach woj. podkarpackiego znajdują się oddziały i filie komercyjnych banków, oferujące kompleksowe pakiety usług finansowych, włącznie z ofertą biur maklerskich i punktami obsługi klienta. W mniejszych ośrodkach i na obszarach wiejskich występują głównie banki spółdzielcze, które oferują ograniczony zestaw świadczeń bankowych. Rozkład instytucji finansowych wykazuje duże dysproporcje. Zlokalizowane są one głównie w miastach, a ich zaangażowanie na obszarach wiejskich jest stosunkowo niewielkie.

Jedynym bankiem z siedzibą centrali na Podkarpaciu jest Rzeszowski Bank Regionalny S.A. Według stanu w końcu 2005 r. zrzeszał 44 banki spółdzielcze i działał na terenie woj. podkarpackiego oraz dwóch gmin pow. gorlickiego w woj. małopolskim. Analiza dostępnych instrumentów finansowych pozwala stwierdzić, że potrzeby finansowe woj. podkarpackiego znacznie przekraczają dostępne na rynku środki finansowe. Z opinii jednostek samorządu terytorialnego ${ }^{9}$ wynika, że mimo dużych możliwości oferty usług finansowych na Podkarpaciu, odczuwalny jest szczególnie brak preferencyjnych źródeł finansowania samorządowych inwestycji infrastrukturalnych.

Tab. 1. Liczba placówek bankowych na Podkarpaciu i w sąsiednich województwach w 2005 r.

\begin{tabular}{|l|c|c|c|c|}
\hline \multirow{2}{*}{ vunuv vannumy } & \multicolumn{4}{|c|}{ Województwo } \\
\cline { 2 - 5 } & podkarpackie & lubelskie & małopolskie & świętokrzyskie \\
\hline Centrale banków & 1 & 3 & 4 & 1 \\
\hline Oddziały, filie & 306 & 308 & 398 & 99 \\
\hline Banki spółdzielcze & 140 & 206 & 147 & 107 \\
\hline Lącznie & $\mathbf{4 4 7}$ & $\mathbf{5 1 7}$ & $\mathbf{5 4 9}$ & $\mathbf{2 0 7}$ \\
\hline
\end{tabular}

Źródło: dane GUS, Warszawa 2006.

$\overline{9}$ Wyniki badań ankietowych przeprowadzonych w 2006 r. w samorządach gmin i powiatów woj. podkarpackiego. 


\section{Izby i stowarzyszenia gospodarcze}

Izby i stowarzyszenia gospodarcze tworzone są z inicjatywy przedsiębiorstw i instytucji publicznych, w celu reprezentowania własnych interesów na zewnątrz. Funkcjonujące w woj. podkarpackim przedsiębiorstwa i instytucje publiczne zajmujące się rozwojem regionalnym podjęły dobrowolne inicjatywy tworzenia izb, stowarzyszeń, klubów w celu reprezentowania ich interesów na zewnątrz. Według stanu 31.12.2006 r. w woj. podkarpackim działały: Regionalna Izba Gospodarcza w Sanoku, Regionalna Izba Gospodarcza w Stalowej Woli, Podkarpacka Izba Gospodarcza w Krośnie, Izba Przemysłowo-Handlowa w Rzeszowie, Izba Rolnicza Województwa Podkarpackiego i Bussines Center Club. Klientami tych instytucji są przedsiębiorcy, kupcy i rzemieślnicy oraz bezrobotni zamierzający rozpocząć działalność na własny rachunek. Na terenie województwa działają izby rolnicze, gospodarcze i izby przemysłowo handlowe.

Zgodnie ze statutem izba jest samodzielną gospodarczą organizacją rządową, samorządową lub organizacją pracodawców, reprezentującą interesy gospodarcze zrzeszonych podmiotów. Zadaniem izby jest reprezentowanie zrzeszonych w niej podmiotów gospodarczych wobec innych instytucji, których funkcjonowanie wywiera wpływ na warunki działalności tych podmiotów. Źródłami finansowania działalności izby są: wpisowe, składki członkowskie, dobrowolne wpłaty zrzeszonych podmiotów, a w okresie członkostwa w UE - znaczne środki z jej budżetu.

\section{Ośrodki wspierania przedsiębiorczości}

Ośrodki wspierania przedsiębiorczości zajmują się pomocą w uruchamianiu działalności gospodarczej i wspierają już istniejące firmy, szczególnie z sektora małych i średnich przedsiębiorstw (MŚP). Instytucje te przede wszystkim świadczą usługi: doradcze, szkoleniowe, informacyjne i finansowe. Ośrodki wspierania przedsiębiorczości skupione są głównie w Krajowym Systemie Usług dla MŚP zarządzanym przez Polską Fundację Promocji i Rozwoju MŚP w Warszawie. Do tej sieci w woj. podkarpackim należą 23 ośrodki, m.in. Rzeszowska Sieć Centrów Wspierania Biznesu przy Stowarzyszeniu Promocji Przedsiębiorczości w Rzeszowie. Do tej kategorii należą również Leżajskie Stowarzyszenie Wspierania Inicjatyw Gospodarczych oraz Inkubator Przedsiębiorczości IN-MARR w Mielcu, który - oprócz kompleksowego konsultingu i kredytów - oferuje powierzchnię produkcyjno-usługową na korzystnych zasadach dla nowo powstających firm ${ }^{10}$.

\section{Centra innowacji i transferu technologii}

Centra innowacji i transferu technologii to instytucje funkcjonujące od 1997 r., zajmujące się wdrażaniem innowacji i transferem technologii, w powiązaniu z restrukturyzacją przedsiębiorstw w niektórych ośrodkach przemysłowych województwa. W woj. podkarpackim działa Centrum Transferu Technologii przy ARR „MARR” S.A. w Mielcu, akredytowane przez Fundację na Rzecz Nauki Polskiej, którego głównym celem jest wspieranie finansowe innowacji i nowych technologii. W fazie organizacji jest Centrum Obsługi Inwestora i Innowacyjności RARR S.A. w Rzeszowie, którego podstawowym celem będzie obsługa inwestorów krajowych i zagranicznych. Wiodącą rolę w zakresie badań dotyczących stosowania najnowszych technologii, zwłaszcza w przemyśle, odgrywa Politechnika Rzeszowska. W procesie transferu technologii uczestniczą także ośrodki badawczo-rozwojowe w Stalowej Woli i Tarnobrzegu. W sektorze rolnym proces transferu innowacji w zakresie rolnictwa i przetwórstwa rolno-spożywczego realizują ośrodki doradztwa rolniczego.

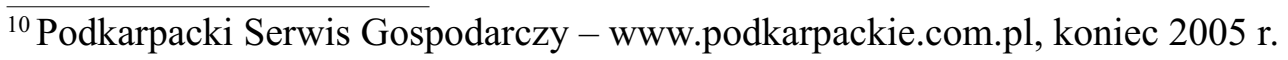




\section{Ośrodki szkoleniowo-konsultingowe}

Działalność j ośrodków szkoleniowo-konsultingowych jest szczególnie potrzebna w okresie funkcjonowania w gospodarce rynkowej, a także w związku z ciągłymi procesami transformacji strukturalnej gospodarki regionu. Uwarunkowania te powodują wzrost zapotrzebowania na różnego rodzaju szkolenia i doradztwo, co z kolei jest przyczyną powstania wielu prywatnych szkół biznesu, centrów edukacji, centrów kształcenia praktycznego i ustawicznego oraz firm konsultingowych. Misją instytucji szkoleniowo-doradczych jest stymulowanie rozwoju gospodarczego woj. podkarpackiego poprzez działalność szkoleniową, doradczą, informacyjną i naukową. Większość z nich znajduje się w Rzeszowie, a szczególną pozycję ma Stowarzyszenie Promocji Przedsiębiorczości. Rozwój ośrodków szkoleniowo-konsultingowych jest szczególnie widoczny w okresie członkostwa we Wspólnocie Europejskiej; szeroki zakres możliwości wsparcia środkami UE wymusza konieczność korzystania z usług konsultingowych i szkoleniowych. Rozwój tych instytucji wspierany jest w znacznym stopniu środkami z budżetu UE w formie programów operacyjnych.

\section{Centra targowe, wystawienniczo-promocyjne, giełdy towarowe}

Elementem wspierającym rozwój biznesu są szeroko rozumiana promocja gospodarcza i tworzenie warunków do współpracy przedsiębiorców, samorządów, a także regionów. Warunki dla tej promocji tworzą instytucje organizujące imprezy wystawienniczo-promocyjne, giełdy towarowe, specjalistyczne wystawy i targi. Najważniejsze z nich odbywają się:

- w Rzeszowie - INTERRES Międzynarodowe Targi Budownictwa, Mebli i Wyposażenia Wnętrz „HOME BUILDING”, Międzynarodowe Targi Rolno-Przemysłowe i Spożywcze „AGROPOL”, Targi Opakowań i Maszyn Pakujących „GAL-OPAK”, Targi Systemów Komputerowych i Oprogramowania „INFOLIVE”;

- w Krośnie - Międzynarodowe Targi „KONTAKT” - targi wielobranżowe skupiające firmy $\mathrm{z}$ regionów przygranicznych.

\section{Instytucje pośrednictwa pracy i przeciwdziałania bezrobociu}

Poza strukturami statutowo odpowiedzialnymi za zwalczanie bezrobocia, czyli wojewódzkimi i powiatowymi urzędami pracy, w woj. podkarpackim działają organizacje pozarządowe organizujące pośrednictwo pracy i inne alternatywne formy przeciwdziałania bezrobociu. Są to m.in.: kluby pracy, centra kształcenia praktycznego i ustawicznego, gminne kluby aktywnego poszukiwania pracy. Działalność tych instytucji jest wspierana środkami UE, pochodzącymi głównie z Europejskiego Funduszu Społecznego.

\section{Jednostki badawczo rozwojowe}

Jednostki badawczo-rozwojowe to sfera nauki reprezentowana przez szkoły wyższe i instytucje naukowe, których głównym zadaniem jest kreowanie innowacyjności i transfer technologii do regionu. Mogą one uczestniczyć w tworzeniu centrów transferu technologii, inkubatorów przedsiębiorczości i inkubatorów technologicznych, parków naukowo-technologicznych ${ }^{11}$.

Dane dotyczące liczby instytucji wspomagających rozwój regionalny i pośredniczących w wykorzystaniu środków UE w odniesieniu do sąsiednich województw przedstawia tab. 2.

${ }^{11}$ W. Burdecka, Instytucje otoczenia biznesu. PARP, Warszawa 2004, s. 25-27. 
Tab. 2. Liczba podmiotów gospodarczych tworzących otoczenie biznesu na Podkarpaciu w 2005 r.

\begin{tabular}{|l|c|c|c|c|}
\hline \multirow{2}{*}{$\begin{array}{c}\text { Przedmiot } \\
\text { dzialalności }\end{array}$} & \multicolumn{3}{|c|}{ Województwo } \\
\cline { 2 - 5 } & podkarpackie & lubelskie & małopolskie & $\begin{array}{c}\text { święto- } \\
\text { krzyskie }\end{array}$ \\
\hline Pośrednictwo finansowe & 614 & 644 & 649 & 562 \\
\hline Ubezpieczenia & 336 & 405 & 448 & 363 \\
\hline Działalność prawnicza & 260 & 305 & 515 & 361 \\
\hline $\begin{array}{l}\text { Księgowość, } \\
\text { doradztwo podatkowe }\end{array}$ & 445 & 491 & 690 & 481 \\
\hline $\begin{array}{l}\text { Badania rynku } \\
\text { Doradztwo w zakresie prowadzenia } \\
\text { działalności gospodarczej }\end{array}$ & 147 & 186 & 343 & 28 \\
\hline $\begin{array}{l}\text { Doradztwo w zakresie wnioskowania } \\
\text { i zarządzania środkami UE }\end{array}$ & 421 & 321 & 389 & 190 \\
\hline Zarządzanie przedsiębiorstwami & 35 & 43 & 51 & 37 \\
\hline Reklama & 336 & 396 & 845 & 344 \\
\hline
\end{tabular}

Źródło: dane GUS, Warszawa 2006.

Instytucje wspierające rozwój regionalny pełnią funkcje doradcze, szkoleniowe, informacyjne, finansowe, proinnowacyjne i rzeczowe. Efektywność realizacji tych funkcji jest uzależniona m.in. od jakości oferty usług, poziomu środków finansowych przeznaczonych na działalność oraz stabilności instytucji. Jakość oferty usług zależy głównie od wiedzy, kwalifikacji i doświadczenia zawodowego pracowników zatrudnionych w tych instytucjach. Stabilność instytucji wyraża czas jej funkcjonowania na rynku: im instytucja działa dłużej, tym ma większe doświadczenie w realizacji swojej misji i jest bardziej znana odbiorcom jej działalności. ${ }^{12}$

Według badań ${ }^{13}$, statystyczna instytucja wspierająca rozwój Podkarpacia działa od 3 do 5 lat i jest zlokalizowana w mieście liczącym do 50 tys. mieszkańców. Instytucje otoczenia najczęściej funkcjonują w formule stowarzyszenia lub fundacji (ryc. 1). Do wykonywanych zadań dostosowują swoje struktury organizacyjne, tworząc oddziały lub podstruktury wewnątrz własnych organizacji. Obszar odbioru oferty (usług) najczęściej pokrywa się z obszarem oddziaływania. Ofertę kierują do małych i średnich firm, osób fizycznych rozpoczynających działalność, samozatrudnionych i osób bezrobotnych, jednostek samorządu terytorialnego.

Wśród badanych instytucji najliczniejszą grupę stanowią organizacje wspierające przedsiębiorców (43\%), inkubatory przedsiębiorczości $(14,4 \%)$, centra transferu technologii $(5,1 \%)$, ośrodki szkoleniowe $(3 \%)$, izby gospodarcze $(2,2 \%)$, parki przemysłowe $(1,8 \%)$ i parki naukowo-techniczne $(1,1 \%)$.

$\overline{{ }^{12}}$ T. Dołęgowski: Konkurencyjność instytucjonalna i systemowa $w$ warunkach gospodarki globalnej, „Monografie i Opracowania”, 505/2002, Wyd. SGH, Warszawa, s. 93 i 94.

${ }^{13}$ Wyniki badań ankietowych. 
Ryc. 1. Forma organizacyjno-prawna badanych instytucji wspierających politykę regionalną Podkarpacia

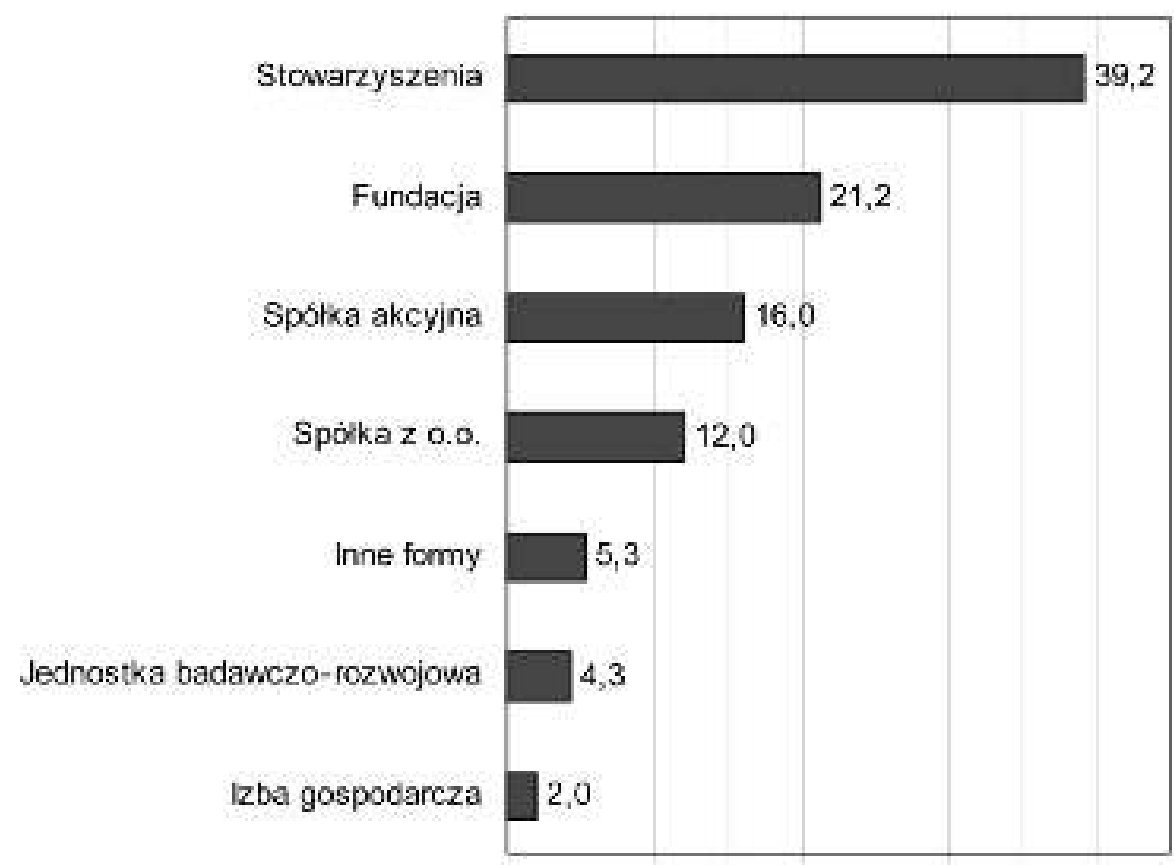

Źródło: opracowanie autora.

Znaczna część działających na Podkarpaciu instytucji zorganizowana jest w formie fundacji i stowarzyszeń (ryc. 1). Ta forma wydaje się być korzystna dla ośrodków innowacyjności i przedsiębiorczości ze względu na konstrukcję systemu podatkowego oraz możliwość pozyskiwania środków rządowych lub pomocy innego typu (głównie funduszy strukturalnych UE). Instytucje wspierające rozwój Podkarpacia zlokalizowane są głównie na terenach miejskich, z czego najwięcej w miastach do 50 tys. mieszkańców $-28,2 \%$. Niewielka liczba instytucji $(1,5 \%)$ zlokalizowana jest na terenach wiejskich.

Badane instytucje różnią się zasięgiem działalności i obszarem odbioru oferty usług. Przeważająca liczba instytucji $(37,2 \%)$ działa na poziomie regionu (ryc. 2). Drugim co do liczebności instytucji obszarem działania jest powiat - 19,7\%.

Badania ankietowe przeprowadzone wśród podmiotów z Podkarpacia wykazują, że z instytucjami wspierającymi rozwój regionu współpracuje jedynie co czwarty mały przedsiębiorca (31,2\% badanych ${ }^{14}$. Najczęściej współpraca dotyczy takich instytucji, jak: urząd pracy, Agencja Rozwoju Regionalnego, ARiMR, banki, organizacje branżowe, ODR (rolnicy). W niewielkim zakresie respondenci wskazywali potrzebę współpracy z ośrodkami badawczo-rozwojowymi oraz instytucjami wyspecjalizowanymi we wspieraniu przedsięwzięć innowacyjnych i transferu technologii. W większości współpraca podmiotów z otoczeniem instytucjonalnym dotyczyła pozyskiwania środków finansowych na różnego rodzaju przedsięwzięcia inwestycyjne, zatrudniania pracowników w ramach programów refundowanych, a także rozwiązywania zwykłych, np. administracyjnych, problemów związanych z prowadzeniem firmy, podejmowaniem i prowadzeniem działalności gospodarczej, wnioskowaniem o fundusze strukturalne UE oraz o pomoc w uzyskaniu zwrotnych środków finansowych. Na efekty współpracy z instytucjami otoczenia biznesu wskazywali głównie przedsiębiorcy, natomiast zdaniem samorządów gmin i powiatów współpraca

\footnotetext{
${ }^{14}$ Badaniem autora $\mathrm{w}$ ramach projektu realizowanego przez Wydział Ekonomii UR w Rzeszowie $\mathrm{w}$ ramach ZPORR dofinansowanego z EFS pt. Tworzenie sieci wspótpracy pomiędzy sektorem badawczo-rozwojowym a przedsiębiorcami, objęto 90 przedsiębiorców i 20 samorządów gmin i powiatów $\mathrm{z}$ terenu woj. podkarpackiego.
} 
pomiędzy tymi jednostkami nie była widoczna. Przedsiębiorcy podkreślali, że efekty współpracy z instytucjami otoczenia biznesu dotyczyły głownie poprawy jakości produktów, możliwości ich zbytu, pomocy w pozyskiwaniu środków finansowych z UE (ryc. 3).

Ryc. 2. Zasięg działania instytucji wspierających politykę regionalną w woj. podkarpackim

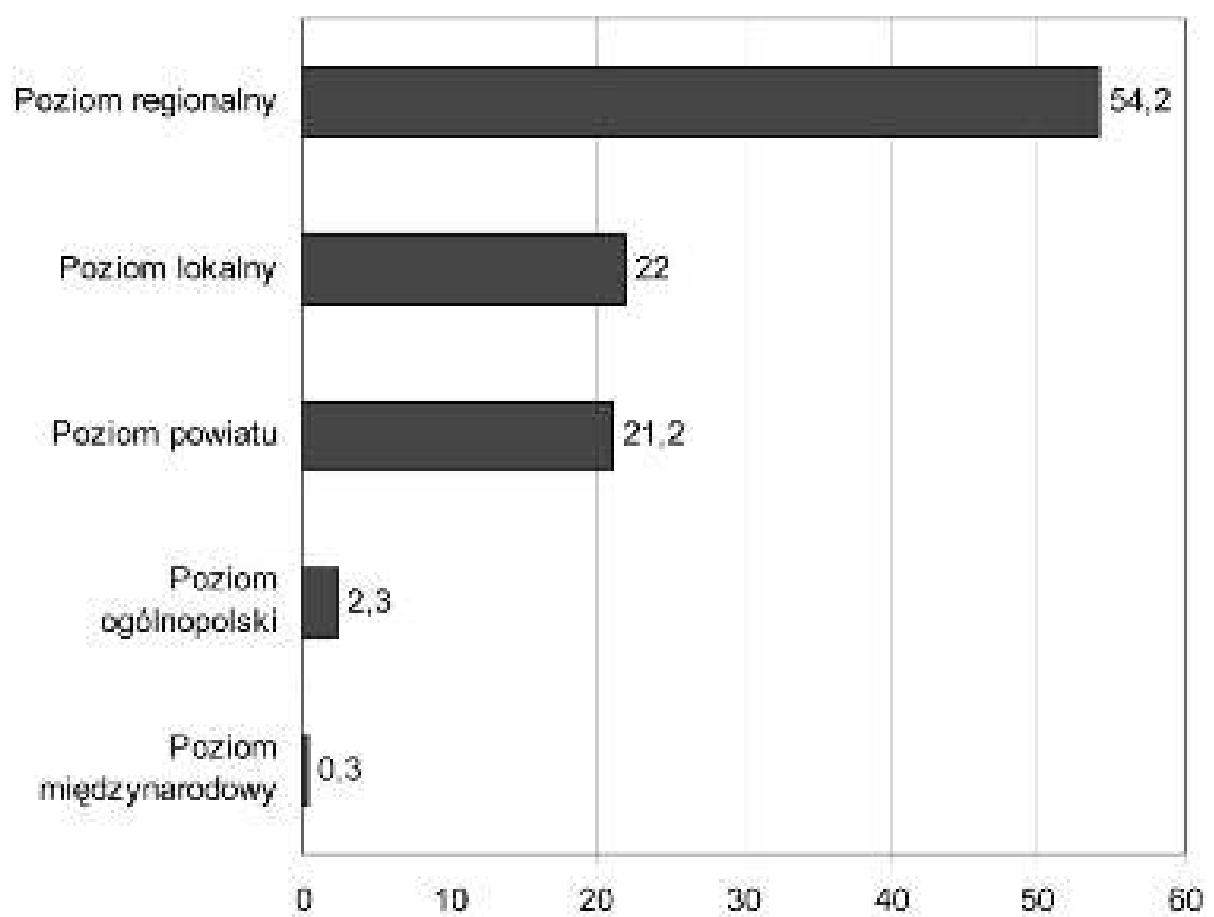

Źródło: opracowania autora.

Ryc. 3. Efekty współpracy jednostek samorządowych i badanej grupy przedsiębiorców z instytucjami otoczenia biznesu w woj. podkarpackim (w \%)

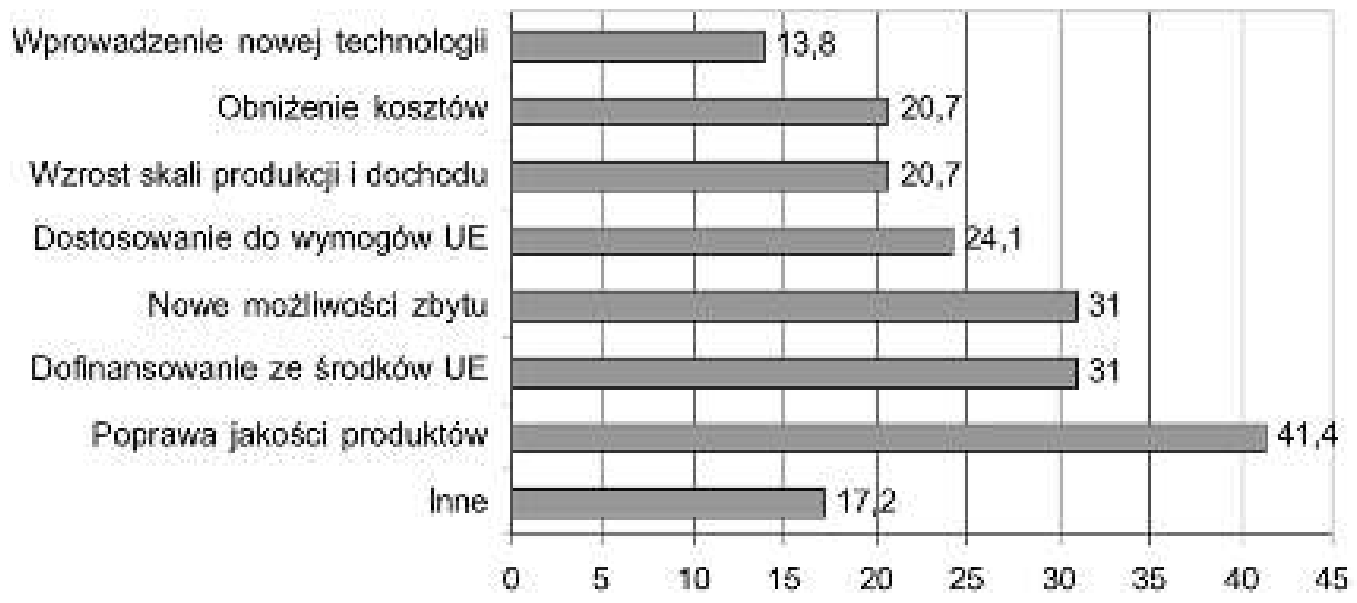

Źródło: opracowania autora.

Wyniki wywiadów pozwalają na wskazanie działań, które w opinii podmiotów z Podkarpacia mogłyby ułatwić współpracę $\mathrm{z}$ instytucjami otoczenia biznesu i podnieść jej efektywność. Można do nich zaliczyć:

- lepsze dostosowanie oferty instytucji wsparcia do potrzeb podmiotów regionu;

- szerszą promocję działalności instytucji wsparcia;

- obniżenie kosztów korzystania z usług instytucji;

- większą aktywność instytucji w terenie, stworzenie zachęty do współpracy;

- odbiurokratyzowanie procedur związanych z korzystaniem ze wsparcia niektórych instytucji. 
Dane empiryczne wskazują, że w woj. podkarpackim działa wiele różnorodnych instytucji wspierających rozwój regionu, a zakres świadczonych przez nie usług jest wielokierunkowy. Różne kategorie usług często się łączą, najczęściej bez względu na nazwę instytucji jej zakres jest uniwersalny, świadczone usługi dostosowywane są do potrzeb odbiorców, a ich jakość może być wątpliwa. Potwierdziły to wyniki badań ankietowych: potencjalni odbiorcy nisko oceniali przede wszystkim jakość usług szkoleniowo-doradczych oraz zakres oferty skierowanej do odbiorców z uwzględnieniem polityki rozwoju regionu. Oferta szkoleniowa, doradcza i informacyjna nie zawsze była dostosowana do potrzeb konkretnych podmiotów. Większość oferowanych informacji miała charakter ogólny, a usługi specjalistyczne wyceniano zbyt wysoko.

W podsumowaniu należy stwierdzić, że region podkarpacki ma duży potencjał instytucjonalny w zakresie wspierania rozwoju regionalnego, dorównujący potencjałowo woj. małopolskiego, o wyższym poziomie rozwoju gospodarczego. Nie jest on w pełni wykorzystywany w odniesieniu do kierunków rozwoju regionu określonych w przyjętej strategii rozwoju oraz w innych dokumentach programowych Podkarpacia.

\section{Literatura}

1. Dołęgowski T., Konkurencyjność instytucjonalna i systemowa w warunkach gospodarki globalnej, „Monografie i Opracowania”, 505/2002, SGH, Warszawa.

2. North D.C., 1990, Institution, Institutional Change and Economic Performance, Cambridge University Press.

3. Wilkin J., 1997, Instytucje i instytucjonalizm w ekonomii, WNE, Warszawa.

4. Wilkin J., 2001, Instytucjonalne uwarunkowania modernizacji wsi w Polsce, ZN AR w Krakowie, nr 377, z. 78, t. I, Kraków.

5. Zeman-Miszewska E., Instytucjonalne formy wspierania przedsiębiorczości, „Prace Naukowe AE we Wrocławiu", 1116/2006, s. 687-691.

\section{The Business Environment Institutions as a Succouring Factor for the Podkarpacie Region}

Institutional infrastructure, consists of economic development agencies, commerce and industry chambers, banks, loan and saving funds, investment companies, development funds, economic support funds, insurance companies etc., is the significant factor in regional development. The Podkarpacie region has a great institutional potential for the support in the regional development; potential equal to the Małopolskie region with highest level of economic development. This potential is not fully used for the directions of the regional development defined in the accepted strategies and in other agendas for Podkarpacie. 